ORIGINAL

\title{
Conservation and chemical composition of Leucaena Leucocephala plus fresh or wilted Pennisetum purpureum mixed silages
}

\section{Conservación y composición de ensilajes mixtos de Leucaena leucocephala con Pennisetum purpureum fresco o presecado}

\author{
Ángel Santana $\mathrm{P}_{1}{ }^{1 *} \mathrm{Ph} . \mathrm{D}$, Mario Cisneros $\mathrm{L}_{1}{ }^{2} \mathrm{Ph} . \mathrm{D}$, Yordan Martínez A, ${ }^{1} \mathrm{Ph} . \mathrm{D}$, \\ Yoandris Pascual S, M.Sc.
}

\begin{abstract}
${ }^{1}$ Universidad de Granma, Facultad de Medicina Veterinaria, Centro de Estudios de Producción Animal, Cuba. ${ }^{2}$ Instituto de Investigaciones Agropecuarias Jorge Dimitrov, Granma, Cuba. *Correspondencia: santana@udg.co.cu
\end{abstract}

Received: July 2014; Acepted: February 2015.

\begin{abstract}
Objective. Quantify the effects of mixing Leucaena (L) with King grass forage, fresh (K) or wilted (Kp), on the fermentation process and chemical composition of mixed silages. Materials and methods. Silos were produced mixing several proportions (kg:kg) K:L and Kp:L (100:0; 75:25; 60:40; 50:50; 40:60 and $0: 100$ ) of both types of plants, under a completely randomized design of four replications. The quantity of organic acids (butyric, acetic, lactic), $\mathrm{pH}$, ammonia nitrogen percent and some of the typical bromatologic nutrients of the forage before and after ensiling were measured. The treatment effects were evaluated through variance and regression analysis. Results. The results clearly proved the differences $(p<0.05)$ between King grass and Leucaena which promote its mixing and wilting: better legume contents of crude protein ( 24 vs. $7 \%$ ), dry matter (33.77 vs. $22.05 \%$ ) and crude fiber (26.53 vs. $32.5 \%)$. Clear benefits on the conservation process of mixed silages were also measured: higher lactic productions and less butyric, acceptable $\mathrm{pH}(4.02-4.8)$ and protein degradation $(<8 \%)$. In addition, a positive effect on the chemical composition of the aforementioned silages was quantified (crude protein, dry matter and crude fiber progressive improvement). Conclusions. Mixed $\mathrm{K}+\mathrm{L}$ silages are better than pure $\mathrm{K}$ if $\mathrm{L}$ is included below $25 \%$ in $\mathrm{KL}$ and up to $40 \%$ when $\mathrm{K}$ has been wilted. Higher inclusions of $L$ will worsen the conservation process and will limit its elaboration.
\end{abstract}

Key words: Ammonia, fermentation, lactic acid, nutrients, ph (Source: DeCS).

\section{RESUMEN}

Objetivo. Cuantificar los efectos de la adición de forraje de Leucaena leucocephala (L) en el proceso fermentativo y la composición química de ensilajes mixtos con King grass fresco (K) o presecado $(\mathrm{Kp})$. Materiales y métodos. Se ensilaron en condiciones de laboratorio diferentes proporciones $(\mathrm{kg}: \mathrm{kg}) \mathrm{K}: \mathrm{L}$ y Kp:L $(100: 0 ; 75: 25 ; 60: 40 ; 50: 50 ; 40: 60$ y $0: 100)$, bajo un diseño totalmente al azar de cuatro repeticiones por cada una. Se midió la cantidad de ácidos orgánicos (butírico, acético, láctico), $\mathrm{pH}$, porcentaje de nitrógeno amoniacal y los nutrientes típicos de la bromatología en el forraje antes de ensilar y en los ensilados resultantes. Los efectos de los tratamientos se midieron mediante análisis de varianza y regresión. Resultados. Los resultados demostraron las diferencias $(p<0.05)$ de la composición química entre el King grass y la Leucaena que animan a su deshidratación previa 
y mezclado: mejores tenores de proteína cruda ( $24 \mathrm{vs.} 7 \%$ ), de materia seca (33.77 vs. 22.05\%) y fibra cruda (26.53 vs. 32.5\%) en la leguminosa; así como los beneficios en la preservación del ensilaje mixto (mejores producciones de ácido láctico y menores del butírico, aceptable pH (4.02-4.8) y degradación de la proteína $(<8 \%)$ y en la bromatología de estos (avance progresivo en la concentración de proteína, materia seca y fibra). Conclusiones. Los ensilajes mixtos $\mathrm{K}+\mathrm{L}$ son mejores que los de $\mathrm{K}$ siempre que $\mathrm{L}$ se adicione hasta $25 \%$ con $\mathrm{K}$ y hasta $40 \%$ con $\mathrm{K}$ presecado. Con inclusiones mayores de Leucaena se empeora la conservación, lo que limita su elaboración.

Palabras clave: Ácido láctico, amoníaco, fermentación, nutrientes, ph (Fuente: DeCS).

\section{INTRODUCTION}

It has been shown that for typical small farmers in the tropics, conservation of surplus forage as silage can be important because this way they can thus avoid the influence of climatic conditions that are adverse to developing hay and because various technological variants can be applied according to changing economic conditions, infrastructure and levels of knowledge (1).

Historically, producers have different species and varieties of grasses to feed their animals which, at the same time, are the basic materials to be preserved for scarcity periods. However, today it is more common to use other forage families to combine with the classic grass-based diets (2).

On the other hand, silage fermentation as warranty of conservation, is a complex process involving relationship between characteristics of the original feed, applied technology, epiphytic microflora of the environment and prevailing weather conditions. (3)

It is known that the grasses are better preserved than legumes due to a higher content of soluble carbohydrates and because they are lower in protein and minerals; but they have lower nutritional value and animal productions are consequently lower. In contrast, leguminous plants produce less desirable fermentations, as they have less fermentable carbohydrates and because they have greater protein and mineral content; however, its use stimulates consumption of silage, digestibility of nutrients, and production aspects such as weight gain and milk yield $(2,4,5)$.

Contrary to this, some research has not reported significant improvements, but rather reductions in some percentage parameters, such as nutrient digestibility coefficients that are included in the nutritional evaluation of silage. Using silage that has the progressive addition of legumes, however, close dependencies with mixed forage species (1) are indicated.

The objective of this research was to quantify the effects of adding Leucaena leucocephala

\section{INTRODUCCIÓN}

Se ha demostrado que para los pequeños ganaderos típicos del trópico la conservación de los excedentes de forrajes en forma de ensilaje puede ser también de gran interés, porque es una técnica que esquiva en gran medida la influencia de las condiciones climáticas que resultan adversas para la elaboración de heno y porque se pueden aplicar variantes tecnológicas ajustables a diversas condiciones económicas, de infraestructura y niveles de conocimientos acerca de la misma (1).

Históricamente los productores han tenido disponibles diferentes especies y variedades de gramíneas forrajeras para alimentar a sus animales que han sido, al mismo tiempo, el material básico a conservar para periodos de escasez. Sin embargo, en la actualidad es más común el cultivo de especies de otras familias forrajeras de alto valor nutricional, con el objetivo de combinar con las dietas clásicas basadas en estas gramíneas (2).

Por otra parte, la fermentación de los ensilajes, entendida como garantía de la conservación, es un proceso complejo que involucra interrelaciones entre las características del forraje original, la tecnología aplicada, la microflora epifítica del ambiente y las condiciones climáticas imperantes (3).

Es conocido que las gramíneas se conservan mejor que las leguminosas por sus mayores contenidos de carbohidratos solubles, y más bajos de proteínas y minerales; pero a su vez tienen menor valor nutritivo y las producciones de los animales son en consecuencia bajas. En cambio las leguminosas producen fermentaciones menos deseables por ser menos ricas en carbohidratos fermentables y por poseer tenores más altos de proteínas y minerales; sin embargo su uso estimula el consumo del ensilaje, la digestibilidad de los nutrientes, y aspectos productivos como la ganancia de peso y la producción de leche $(2,4,5)$.

Contrario a lo anterior algunas investigaciones no han reportado mejoras significativas, más 
forage in the fermentation process and chemical composition of silage mixed with fresh or wilted King grass (Pennisetum purpureum cv. King grass).

\section{MATERIALS AND METHODS}

Site and type of experiment. The experiment was carried at laboratory level in the research facilities of the Centro de Estudios de Producción Animal, Faculty of Veterinary Medicine, Universidad de Granma; eastern region of Cuba (Coordinates: 200, 16',52.596" North latitude, 760, 43', 36.192" East longitude, and altitude of $112.5 \mathrm{~m}$ asl), tropical brown soil free of carbonates, $3.3 \%$ of organic matter, and pH from neutral to slightly acid (6).

Procedure. Several Cullison type of microsilos (1.2 L of capacity), with Bunsen copper valves to avoid air entering, were used to ensile different mixtures of fresh King grass (K) or sun predehydrated $(\mathrm{Kp})$ during 4 hours having 80 days of regrowth (pre-bloom stage) plus Leucaena (L). Both type of forages were chopped (1-1.5 $\mathrm{cm}$ long) and mixed in proportions $(\mathrm{kg}: \mathrm{kg})$ of $100: 20 ; 75: 25 ; 60: 40 ; 50: 50 ; 40: 60$ and $0: 100$ of King grass:Leucaena.

Forage was established in dry areas for a period of 14 months and Leucaena foliage consisted of leaves and tender stems considered to be edible.

Laboratory analysis. 75 days after ensiling the silos were opened to measure $\mathrm{pH}$ using a potentiometer, organic acids (lactic, acetic and butyric acids) by volume (Lepper-Flieg method), $\mathrm{NH}_{3}$ to $\mathrm{N}$ Total by micro diffusion and bromatologic components using AOAC methods (7): dry matter (MS), crude protein (PB), crude fiber (FB), nitrogen free extract (ELN), ether extract (EE), organic matter (MO) and total ash (CZ).

The samples were dried and ground before doing bromatological analysis and fresh silages were diluted in deionized water for organic acids quantification.

Experiment design and statistical analysis. The research was conducted under a $2 \times 6$ factorial design (factor 1 , level of dryness of King grass: fresh $\mathrm{K}$ or pre-dried for 4 hours $\mathrm{Kp}$; factor 2 , six ratios described) with four replications per treatment $(\mathrm{N}=48)$. One-Way analysis of variance for bromatology was conducted on mixed fodder ( $K, K p$ and $L$ ) as sources of variation and Two-Ways analysis of variance for $\mathrm{pH}$ and $\mathrm{NH}_{3}$ (the two factors described and their bien hasta disminuciones de algunos parámetros porcentuales, como en los coeficientes de digestibilidad de los nutrientes que se incluyen en la valoración nutritiva de ensilados al utilizar ensilajes con adición progresiva de leguminosas, no obstante, se indican estrechas dependencias con las especies de forrajes mezcladas (1).

El objetivo de la presente investigación fue cuantificar los efectos de la adición de forraje de Leucaena leucocephala en el proceso fermentativo y la composición química de ensilajes mixtos con King grass (Pennisetum purpureum vc. King grass) fresco o presecado.

\section{MATERIALES Y MÉTODOS}

Sitio y tipo de experimento. El experimento en condiciones de laboratorio se desarrolló en las áreas investigativas del Centro de Estudios de Producción Animal de la Facultad de Medicina Veterinaria de la Universidad de Granma, en la región oriental de Cuba (Coordenadas: $20^{\circ}, 16^{\prime}, 52.596^{\prime \prime}$ latitud Norte y $76^{\circ}, 43^{\prime}, 36.192^{\prime \prime}$ longitud Oeste, a una Altitud de $112.5 \mathrm{msnm}$ ), con un régimen de precipitaciones anuales de $1,600 \mathrm{~mm}$ ( $60 \%$ ocurren en la época lluviosa), suelo de tipo pardo tropical sin carbonato, con contenido de materia orgánica de $3.3 \%$ y pH de neutro a ligeramente ácido (6).

Procedimiento. Se utilizaron microsilos tipo Cullinson de $1.2 \mathrm{~L}$ de capacidad, con válvulas Bunsen de cobre para permitir la salida de los gases y evitar la entrada de aire, donde se ensilaron mediante compactación manual diferentes mezclas de King grass fresco $(K)$ de 80 días de rebrote, sin señales de floración; o Presecado $(\mathrm{Kp})$ previamente durante 4 horas al sol y Leucaena (L), troceados a $1-1.5 \mathrm{~cm}$ de largo y misturados en proporciones en base a peso fresco $(\mathrm{kg}: \mathrm{kg})$ de 100:0; 75:25; 60:40; $50: 50 ; 40: 60$ y $0: 100$ de King grass: Leucaena.

Los forrajes estaban establecidos en áreas de secano por un periodo de 14 meses y el follaje de Leucaena consistió en hojas y tallos tiernos considerados como comestibles por los animales.

Análisis de laboratorio. A los 75 días de elaborados los silos, fueron abiertos para realizar las mediciones del $\mathrm{pH}$ por potenciometría, los ácidos orgánicos (láctico, acético y butírico) por volumetría (método Lepper-Flieg), el $\mathrm{NH}_{3}$ respecto al $\mathrm{N}$ Total por microdifusión y también los componentes bromatológicos por los métodos de la AOAC (7): materia seca (MS), proteína cruda (PB), fibra cruda (FB), extracto 
interaction as fixed effects). Correlation and regression analysis were done too. In al cases values of $p<0.05$ were considered significant.

Also, variation adjustment $(\mathrm{Y})$ in bromatology and synthesis of organic acids was tried with three types of regression equations (linear, quadratic and cubic), where the independent variable $(X)$ was the percentage of Leucaena in silage.

The best equation was selected according to the highest value of $\mathrm{R}^{2}$ (for more accuracy), as long as it was higher by at least 0.05 units compared to less complex ones (for ease of calculations). The standard error of $Y$ estimates was included and it was also considered that residuals were normally distributed.

The values of " $X$ " where " $Y$ " has its maximum and minimum points in quadratic equations were determined as equaling zero with the first derivatives. All statistical analysis were performed using the Statistica de StatSoft program (8).

\section{RESULTS}

Table 1 shows some important differences between the three forages used before ensiling. It should be noted that MS significantly increased in dehydrated King grass forage in comparison with fresh grass, and it was also higher than the quantified value in Leucaena. PB contents found in this legume are greater than the grass in both forms.

Similarly, Leucaena is also favored in its FB and EE content, which may improve the chemical composition of silage when mixed with grass.

Tabla 1. Bromatologic composition (Dry Matter Basis, $\%)$ of forage before silage.

\begin{tabular}{llll}
\hline & $\mathbf{K}$ & $\mathbf{K p}$ & $\mathbf{L}$ \\
\hline MS & $22.05^{\mathrm{c}}$ & $42.31^{\mathrm{a}}$ & $33.77^{\mathrm{b}}$ \\
& \pm 2.88 & \pm 3.85 & \pm 4.61 \\
$\mathrm{MO}$ & 88.67 & 85.11 & 90.05 \\
& \pm 10.0 & \pm 9.12 & \pm 11.2 \\
$\mathrm{CZ}$ & 11.33 & 14.89 & 9.95 \\
& \pm 2.19 & \pm 3.00 & \pm 3.05 \\
$\mathrm{~PB}$ & $7.14^{\mathrm{b}}$ & $6.00^{\mathrm{b}}$ & $24.00^{\mathrm{a}}$ \\
& \pm 0.99 & \pm 0.55 & \pm 1.87 \\
$\mathrm{FB}$ & $32.60^{\mathrm{a}}$ & $39.70^{\mathrm{a}}$ & $26.53^{\mathrm{b}}$ \\
& \pm 4.11 & \pm 4.93 & \pm 2.22 \\
$\mathrm{EE}$ & $1.05^{\mathrm{b}}$ & $0.71^{\mathrm{b}}$ & $2.50^{\mathrm{a}}$ \\
& \pm 0.05 & \pm 0.04 & \pm 0.19 \\
ELN & $47.88^{\mathrm{a}}$ & $38.70^{\mathrm{b}}$ & $37.02^{\mathrm{b}}$ \\
& \pm 3.66 & \pm 4.00 & \pm 3.08 \\
\hline
\end{tabular}

$a, b$ Different letters in the same row indicate significant differences in the Duncan test.

Average \pm DS libre de nitrógeno (ELN), extracto etéreo (EE), materia orgánica (MO) y cenizas totales (CZ).

Las muestras fueron secadas y molidas antes de los análisis bromatológicos y para la cuantificación de los ácidos orgánicos el ensilaje fresco se usó una dilución en agua desionizada.

Diseño experimental y análisis estadísticos. La investigación se llevó a cabo bajo un diseño factorial 2x6 (factor 1 , nivel de sequedad del King grass: fresco $\mathrm{K}$ o presecado por 4 horas $\mathrm{Kp}$; factor 2, las seis proporciones descritas) con cuatro repeticiones por tratamiento $(\mathrm{N}=48)$. Se realizaron análisis de varianza simple para la bromatología, con los forrajes mezclados ( $\mathrm{K}, \mathrm{Kp}$ y L) como fuentes de variación y doble para $\mathrm{pH}$ y $\mathrm{NH}_{3}$ (los dos factores descritos y su interacción, como efectos fijos), de correlación y de regresión. En todos los casos se consideró significativo todo valor de $\mathrm{p}<0.05$.

También se probó el ajuste de la variación (Y) de la bromatología y de la síntesis de ácidos orgánicos a tres tipos de ecuaciones de regresión (lineal, cuadrática y cúbica), donde la variable independiente $(X)$ fue el porcentaje de Leucaena en el ensilado.

Se seleccionó la mejor ecuación según el valor más alto de $\mathrm{R}^{2}$ (para garantizar precisión) siempre que este sea superior al menos 0.05 unidades en comparación con los de menor complejidad (para facilitar los cálculos), se incluyó el Error Estándar de la $Y$ estimada $\left(E_{Y}\right)$ y además se tuvo en cuenta que los residuales se mantuvieran normalmente distribuidos.

Los valores de " $X$ " donde " $Y$ " tiene sus puntos máximos y mínimos en las ecuaciones cuadráticas se determinaron igualando a cero sus primeras derivadas. Todos los análisis estadísticos se llevaron a cabo mediante el programa Statistica de StatSoft (8).

\section{RESULTADOS}

En la tabla 1 se aprecian algunas diferencias importantes entre los tres forrajes utilizados antes de ser ensilados, es preciso destacar que la MS aumentó significativamente en el forraje de King grass deshidratado con respecto a su estado fresco, además fue superior al valor cuantificado en la Leucaena. En cambio los tenores de PB encontrados en esta leguminosa son mayores que el de la gramínea en sus dos formas.

Asimismo, la Leucaena es igualmente favorecida por sus contenidos de $\mathrm{FB}$ y EE, lo que podrá 
On the other hand, the fractions MO and ash showed no important differences between the two forages studied.

The variation in synthesis of lactic, acetic and butyric acids with the progressive addition of Leucaena to ensiled mixture is shown in figure 1. Importantly, butyric acid production, both $\mathrm{KL}$ and $\mathrm{KPL}$, increased from $50 \%$ inclusion of the legume in comparison with the control ( $0 \%$ of Leucaena), with greater emphasis on $\mathrm{KL}$ treatment. In this sense, when making calculations with equations, it was found that $K_{p} L$ has a minimum production of this acid with inclusions of up to $27 \%$ of the legume and equal to $100 \mathrm{King}$ grass ( 0 Leucaena), with a rate of $47 \mathrm{~K}: 53 \mathrm{~L}$.

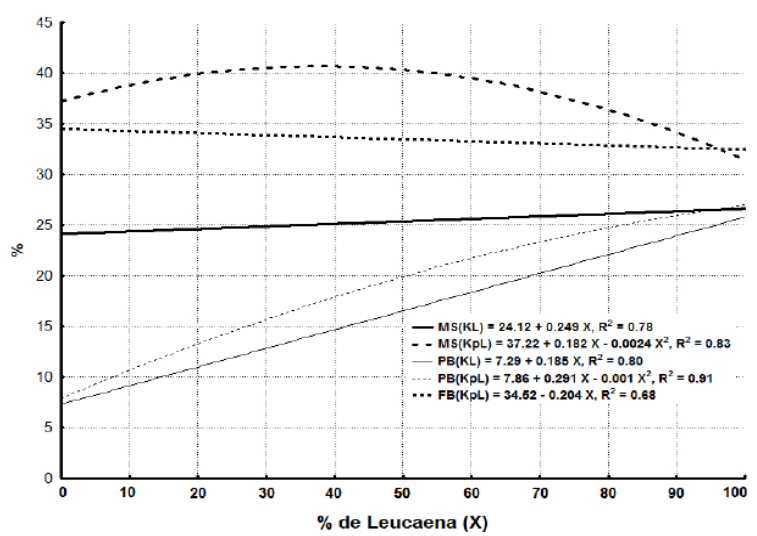

Figure 1. Effects of adding increasing Leucaena forage on the production of butyric, lactic and acetic acid in silages with fresh King grass $(\mathrm{KL})$ or pre-dried King grass (KPL).

For lactic acid, the plotted variation indicated that this is synthesized in the same, or slightly higher, quantities than grass alone when small amounts of Leucaena are included. The estimates indicate that adding up to $7 \%$ of Leucaena in the mix with $\mathrm{KL}$ and up $11 \% \mathrm{~K}_{\mathrm{p}} \mathrm{L}$ improves lactate synthesis.

It is also seen in figure 1 that with $\mathrm{KL}$ it was possible to produce lactic acid in a similar concentration with that of control $\mathrm{KL}$ with $0 \%$ Leucaena, in a mixture with 69.5:30.5 (Kp: L) according to the equation for this acid.

In the case of acetic acid in $\mathrm{KL}$, there was no trend that would fit the evaluated equations. However, in $\mathrm{K}_{\mathrm{p}} \mathrm{L}$ a gradual increase was observed, but with less variation, as more Leucaena was added to the mixture, which also showed the beneficial effect of wilting the grass. mejorar la composición química del ensilaje al ser mezclada con la gramínea.

De otro lado, las fracciones de MO y cenizas no mostraron diferencias significativas entre los tres forrajes estudiados.

La variación en la síntesis de los ácidos láctico, acético y butírico con adición progresiva de follaje de Leucaena a la mezcla ensilada se muestra en la figura 1. Es importante notar que la producción de ácido butírico, tanto en $\mathrm{KL}$ como en $\mathrm{KpL}$, aumentó a partir del $50 \%$ de inclusión de la leguminosa en comparación con el tratamiento control ( $0 \%$ de Leucaena), con mayor énfasis en el KL. En este sentido al realizar los cálculos con las ecuaciones, se encontró que el $\mathrm{KpL}$ tiene una producción mínima de este ácido con inclusiones de hasta $27 \%$ de la leguminosa e igual al 100 de King grass (0 de Leucaena), con una proporción de $47 \mathrm{~K}: 53 \mathrm{~L}$.

Para el ácido láctico, la variación graficada indicó que este se sintetiza en cantidades iguales, - ligeramente superiores a la gramínea sola cuando se incluye poca cantidad de Leucaena. Las estimaciones permiten afirmar que la adición de hasta $7 \%$ de Leucaena en la mezcla con $\mathrm{KI}$ y hasta $11 \%$ con $\mathrm{KpL}$ mejora la síntesis de los lactatos.

Se aprecia también en la figura 1 que con $\mathrm{KpL}$ se logró producir el ácido láctico en una concentración similar a la del testigo $\mathrm{KL}$ con $0 \%$ de Leucaena, con una mezcla 69.5:30.5 (Kp:L), según la ecuación de ajuste para este ácido.

Para el caso del ácido acético en KL no se encontró una tendencia que se ajustara a las ecuaciones evaluadas. Sin embargo, en KpL se observó un incremento paulatino, pero de menor variación, en la medida que se adicionó más Leucaena a la mistura, lo que comprobó también un efecto benéfico del presecado previo de la gramínea.

La tabla 2 muestra el $\mathrm{pH}$ de las mezclas y el porcentaje de $\mathrm{N}$ amoniacal en relación al total cuantificado que se relaciona clásicamente con el nivel del deterioro de las proteínas. La comparación de los valores medios de $\mathrm{pH}$ entre los tratamientos tiene una importancia menor que la observancia de su variación conforme aumenta el porcentaje de Leucaena en la mixtura, para poder evaluar con sentido práctico los efectos de este último. Nótese que se observa un aumento para ambos tipos de ensilados, aunque en $\mathrm{KL}$ la inclusión de $25 \%$ de Leucaena provocó un ascenso significativo del $\mathrm{pH}$ desde 4.02 que es un valor cercano al ideal de 4 . 
Table 2 shows the $\mathrm{pH}$ of the mixtures and the percentage of ammonium nitrogen relative to the quantified total that is classically related to the level of protein deterioration. Comparing the mean $\mathrm{pH}$ values between treatments is less important that observing its variation as the percentage of Leucaena increases in the mixture, in order to assess the practical effects of the latter. An increase for both types of silage is observed, although in $\mathrm{KL}$ inclusion at $25 \%$ Leucaena caused a significant rise in $\mathrm{pH}$ from 4.02 to a value close to the ideal 4 .

Table 2. $\mathrm{pH}$ and $\mathrm{NH}_{3}-\mathrm{N}$ of silages.

\begin{tabular}{|c|c|c|c|}
\hline $\begin{array}{c}\text { Forage } \\
\text { (1) }\end{array}$ & $\begin{array}{l}\% \text { L } \\
\text { (2) }\end{array}$ & $\begin{array}{c}\text { pH } \\
\pm \mathrm{DS}\end{array}$ & $\begin{array}{l}\mathrm{NH}_{3} \\
\pm \mathrm{DS}\end{array}$ \\
\hline \multirow{10}{*}{$\mathrm{K}$} & \multirow{2}{*}{0} & $4.02^{\mathrm{a}}$ & $5.21^{\mathrm{b}}$ \\
\hline & & \pm 0.02 & \pm 0.57 \\
\hline & \multirow{2}{*}{25} & $4.42^{\mathrm{bc}}$ & $5.54^{\mathrm{bc}}$ \\
\hline & & \pm 0.22 & \pm 0.71 \\
\hline & \multirow{2}{*}{40} & $4.37^{c}$ & $4.95^{b}$ \\
\hline & & \pm 0.20 & \pm 1.19 \\
\hline & \multirow{2}{*}{50} & $4.75^{\mathrm{bd}}$ & $7.80^{d}$ \\
\hline & & \pm 0.24 & \pm 1.19 \\
\hline & \multirow{2}{*}{60} & $4.64^{\text {bce }}$ & $8.56^{d}$ \\
\hline & & \pm 0.08 & \pm 2.36 \\
\hline & 100 & ND & ND \\
\hline \multirow{11}{*}{$\mathrm{Kp}$} & \multirow[b]{2}{*}{0} & $4.19^{\mathrm{abcd}}$ & $2.52^{\mathrm{a}}$ \\
\hline & & \pm 0.07 & \pm 0.54 \\
\hline & \multirow{2}{*}{25} & $4.16^{\mathrm{abc}}$ & $4.88^{b}$ \\
\hline & & \pm 0.11 & \pm 1.13 \\
\hline & \multirow{2}{*}{40} & $4.88^{\text {def }}$ & $7.25^{\mathrm{cd}}$ \\
\hline & & \pm 0.06 & \pm 1.01 \\
\hline & \multirow{2}{*}{50} & $5.20^{9}$ & $8.81^{\mathrm{d}}$ \\
\hline & & \pm 0.23 & \pm 1.70 \\
\hline & \multirow[t]{2}{*}{60} & $5.05^{f g}$ & $9.03^{d}$ \\
\hline & & \pm 0.23 & \pm 1.40 \\
\hline & 100 & ND & ND \\
\hline INTERAC & $\sqrt{1 \times 2}$ & $p=0.0008$ & $p=0.0903$ \\
\hline
\end{tabular}

With the previously wilted grass in the control treatment $(100 \% \mathrm{Kp})$, the $\mathrm{pH}$ begins to progressively increase starting at 4.19 , which is statistically equal to its similar percentage of Leucaena in $\mathrm{Kl}$, which is the initial cause so that the recorded measurements with successive additions of Leucaena exceed 5 in 50:50 proportion.

In $\mathrm{KL}$ the $\mathrm{pH}$ increased highly adjusted $\left(R^{2}=0.78\right)$ to the equation $\mathrm{pH}=4.09+0.01$ $(\% L)$, the same as in the $K_{p} L$ mixtures was adjusted $\left(\mathrm{R}^{2}=0.87\right) \mathrm{pH}=4.12+0.02(\% \mathrm{~L})$, which indicates an intercept, or initial $\mathrm{pH}$ with pure grass, higher in this latter mixture and also a greater slope that signals the greater effect that Leucaena has when King grass was dehydrated beforehand.

The effects caused by the progressive addition of Leucaena to the bromatology of the mixed silage is shown in figure 2 . The contribution of each forage silage mix is perceived. Thus, it was found that the concentrations of PB increased almost linearly with the proportion of Leucaena.
Con la gramínea previamente deshidratada, en el tratamiento testigo ( $100 \% \mathrm{Kp})$ el pH comienza un aumento progresivo que inicia de 4.19 , que estadísticamente es igual a su similar por ciento de Leucaena en $\mathrm{KI}$, siendo la causa inicial de que las mediciones registradas con las adiciones sucesivas de Leucaena lleguen a sobrepasar el valor 5 en las proporciones 50:50.

En $\mathrm{KL}$ el $\mathrm{pH}$ aumentó altamente ajustado $\left(R^{2}=0.78\right)$ a la ecuación $\mathrm{pH}=4.09+0.01(\% \mathrm{~L})$, igual que en las mezclas $\mathrm{KpL}$ se ajustó $\left(R^{2}=0.87\right)$ $\mathrm{pH}=4.12+0.02(\% \mathrm{~L})$, lo que indica un intercepto, o pH inicial con la gramínea pura, más alto en esta última mezcla y también una mayor pendiente como muestra del efecto mayor de la Leucaena cuando el King grass fue deshidratado previamente.

Los efectos provocados por la adición progresiva de Leucaena en la bromatología de los ensilajes mixtos se muestran en la figura 2 . Se percibe la contribución de cada forraje al ensilaje de la mezcla. Así, se encontró que el tenor de PB incrementó prácticamente de forma lineal con la proporción de Leucaena.

El contenido de MS está también influenciado por los forrajes originales, teniendo en cuenta que el forraje de King grass fresco contiene alrededor de $22 \%$ y la Leucaena casi 34 , por lo que sus diferentes mezclas $\mathrm{KL}$ estuvieron en ese intervalo. Igual efecto se puede apreciar para $\mathrm{KpL}$ y en la $\mathrm{FB}$ de $\mathrm{KpL}$; sin embargo, la variación observada en la FB de KL no se ajustó a los modelos evaluados.

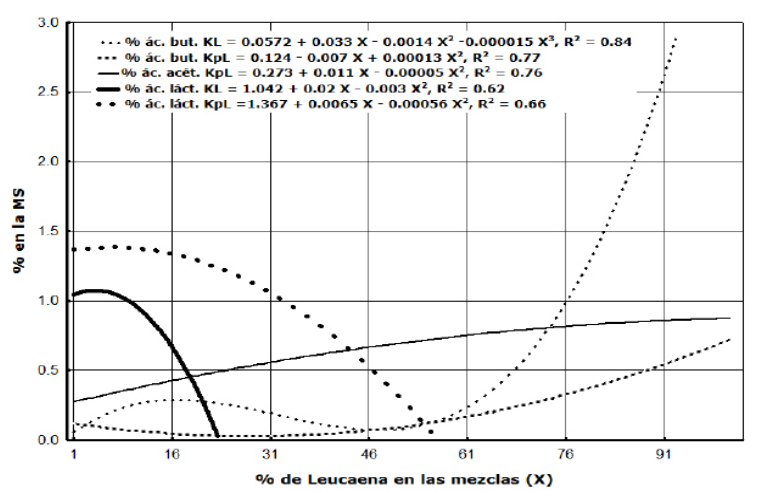

Figure 2. Variation of the MS, $P B$ and $F B$ in silages according to the proportion of Leucaena in the mix.

\section{DISCUSIÓN}

Las diferencias significativas entre los tenores de PB de la Leucaena y la gramínea, en sus dos formas, resulta ser uno de los atractivos más importantes para efectuar la operación de 
The MS content is also influenced by the original forages, considering that fresh King grass forage contains about $22 \%$ and Leucaena nearly 34 , so different $\mathrm{KL}$ mixtures were in that range. The same effect can be seen for $\mathrm{K}_{\mathrm{p}} \mathrm{L}$ and the FB of $\mathrm{K}_{\mathrm{p}} \mathrm{L}$; however, the observed variation in the $\mathrm{FB}$ of $\mathrm{KL}$ did not conform to the models tested.

\section{DISCUSSION}

Significant differences between PB contents of Leucaena and grass, in its two forms, is one of the most important encouraging elements in mixing these two, with the aim of improving the nutritional quality of the resulting mixed silage. Other research $(9,10)$ has confirmed the differences of these concentrations between grasses and legumes. This principle is also reflected in the composition of the mixtures used, as evidenced by higher values than single grasses that are reported in combinations with several tropical legume species $(11,12)$ which are logically determined by the proportions of the two types of plants found in the mixture $(13,14)$.

From the point of view of fermentation, if the silage does not have more than $0.5 \%$ of butyric acid in the MS, the nutritional quality and fermentation (15) is not affected, but above this is proof that Clostridia has dominated the conservation and therefore the response in animals is not positive.

The results show that the percentage of butyric acid reaches about $0.5 \%$ only when $\mathrm{L}$ represents more than $60 \%$ of the $\mathrm{KL}$ mixture and more than 80 in $K_{p} \mathrm{~L}$.

All this happens in grasses-legumes mixtures where a new substrate is created and there are, in addition to the sugars needed for fermentation, greater sources of nitrogen and vitamins than when pure grasses are ensiled. However, the "best" would be to leave it to the point where the sugars do not limit and/or the buffering effects do not impose (1.3).

It has been known for a long time that wilting tropical forages is one of the best ways to lead fermentation to a lactic pattern (16), which is the most desirable in fermentation because it is stronger than others, causes greater decreases in $\mathrm{pH}$, reduces MS loss and stimulates silage consumption by ruminants. It is advisable to avoid Pennisetum silage when it has not been dried previously or any kind of additive is used (17). mezclado de estas, con el objetivo de mejorar la calidad nutritiva del ensilado mixto resultante. Otras investigaciones $(9,10)$ han confirmado las diferencias de estas concentraciones entre gramíneas y leguminosas. Este principio se ve reflejado también en la composición de las mezclas de las especies en cuestión, como lo demuestran los valores superiores a los de las gramíneas solas reportados en combinaciones con varias especies leguminosas tropicales $(11,12)$, lógicamente estarán determinados por las proporciones en que se encuentran los dos tipos de plantas en la mezcla $(13,14)$.

Desde el punto de vista fermentativo se considera que si el ensilado no posee más de $0.5 \%$ de ácido butírico en la MS no se afecta su calidad nutricional, ni su fermentación (15), pero por encima de este es muestra de que los Clostridios han dominado la conservación de la masa y por ende la respuesta en los animales no es positiva.

Los resultados muestran que el porcentaje de ácido butírico llegan cerca de $0.5 \%$ únicamente cuando $\mathrm{L}$ representa más del $60 \%$ en la mezcla $\mathrm{KL}$ y más de 80 en $\mathrm{KpL}$.

Todo lo anterior se debe a que al mezclar gramíneas y leguminosas se crea un medio que posee, además de los azúcares necesarios para la fermentación, mayores fuentes de nitrógeno y vitaminas que cuando se ensilan las gramíneas solamente; no obstante, el "mejor" será hasta el punto donde los azúcares no sean limitantes y/o los efectos buferantes no sean demasiado imponentes $(1,3)$.

También se reconoce desde hace mucho tiempo que el presecado previo de los forrajes tropicales es una de las mejores formas de conducir las fermentaciones hacia el patrón láctico (16), que es el más deseable en la fermentación porque es más fuerte que los demás, provoca descensos mayores en el $\mathrm{pH}$, reduce las pérdidas de MS y estimula el consumo del ensilaje por los rumiantes. Es recomendable evitar el ensilado de los Pennisetum cuando este no ha recibido un marchitamiento previo o se usa algún tipo de aditivo (17).

Indudablemente en el presente experimento esto queda demostrado pues la síntesis de ácido láctico aumenta inicialmente más en $\mathrm{KpL}$ que en $\mathrm{KL}$. En ensilajes de Rye grass+Trébol se obtuvo una síntesis de ácido láctico superior al $5 \%$ y de ácido butírico por debajo de 0.04 en la MS, en cambio el $\mathrm{pH}$ de la masa fue de 4.5 ; pero se consideró aceptable pues la materia seca superó el $43 \%$, también se coincidió con investigaciones hechas con misturas de titricale+veza que poseen valores de $\mathrm{pH}$ por encima de 4.5 y materia seca superior a $40(17,18)$. 
Certainly in this experiment this was demonstrated, since the lactic acid synthesis initially increases more in $\mathrm{K}_{\mathrm{p}} \mathrm{L}$ than in $\mathrm{KL}$. In Rye grass+Clover silage, a lactic acid synthesis above $5 \%$ and butyric acid below 0.04 in the MS was obtained, and the $\mathrm{pH}$ of the mass was 4.5. However, it was considered acceptable because the dry matter exceeded $43 \%$, and it also coincided with investigations with triticale+vetch mixtures that possess $\mathrm{pH}$ values above 4.5 and dry matter greater than $40(17,18)$.

The theory of the various origins of acetic acid in silage explains the irregularities seen in this and similar experiments, including studies using corn to try to reach a better fermentation (1920). When this acid is produced in concentrations higher than $3 \%$ based on dry matter, it can reduce consumption of silage, although such a statement is still inconsistent. In a study of corn silage mixed with a legume (50:50), the $\mathrm{pH}$ was 4.66, even though it has good fermentation, nutritional quality and $\mathrm{NH}_{3}-\mathrm{N}$ accounted for only $6 \%$ (14).

In Sorghum almum mixtures with Arachys hipogea and Centrosema pascorum ensiled without additives, $\mathrm{pH}$ values above 5 (21) were recorded, and the main cause is attributed to the lack of soluble carbohydrates. The opposite effect was found when mixtures of corn stubble with legume Lupinus exaltatus and $L$. rotundiflorus, adding molasses as a carbohydrate source, and it was possible to lower the $\mathrm{pH}$ to values close to 4, although there is a tendency to be higher with greater proportions of the legumes (20).

The strength of synthesized acids in silage can be summarized with $\mathrm{pH}$ measurement and the values of this variable decrease to intervals of 3.6-4.5 ideally, so that the values obtained in the present investigation are considered acceptable for preserving mixtures with less than 50\% Leucaena, whether or not the King grass was predried, even though pre-drying and the presence of legumes are valid reasons so that the $\mathrm{pH}$ reaches above normal values; for this reason, two samples of silage can have the same $\mathrm{pH}$, but different concentrations of acid and vice versa.

Moreover, the values of the interaction between the form of King grass forage (fresh or predried) vs. the percentage of Leucaena in the mixture denote that it is not possible to isolate the influence of both factors in the $\mathrm{pH}$. This means that, regarding the acidity of the silage, it is necessary to consider each one as separate material when the grass is combined independently (fresh or pre-dried) and percent of legume; while regarding the $\mathrm{NH}_{3}$ it is feasible to say that a lower relative protein degradation
La teoría de los diversos orígenes del ácido acético en los ensilados explica las irregularidades apreciadas en la presente investigación y en otras similares, lo que incluye estudios con granos de maíz para tratar de conducir mejor la fermentación $(19,20)$. Cuando este ácido se produce en concentraciones superiores al 3\% en base a la materia seca, puede deprimir el consumo del ensilado, aunque tal afirmación es hoy aún inconsistente. En un estudio con ensilado mixto de maíz con una leguminosa (en proporción 50:50) el pH fue de 4.66, a pesar de poseer buena calidad nutricional, fermentativa y que el $\mathrm{NH}_{3}-\mathrm{N}$ representó sólo el 6\% (14).

En mezclas de Sorghum almun con Arachys hipogea y con Centrosema pascorum ensiladas sin aditivos se registraron valores de $\mathrm{pH}$ superiores a 5 (21) y la causa principal se le atribuye a la falta de carbohidratos solubles. El efecto contrario se comprobó cuando se ensilaron mezclas de rastrojos de maíz con las leguminosas Lupinus exaltatus y $L$. rotundiflorus, pero con la adición de melaza como fuente de carbohidratos, donde se logró descender el $\mathrm{pH}$ hasta valores cercanos a 4, aunque hay una tendencia a ser más elevado en las proporciones más altas de las leguminosas (20).

La fortaleza de los ácidos sintetizados en el ensilado puede ser resumida con la medición del $\mathrm{pH}$ y los valores de esta variable disminuyen hasta intervalos entre 3.6-4.5 idealmente, por lo que los obtenidos en la presente pesquisa están considerados como aceptables para la preservación de las mezclas que poseen menos de $50 \%$ de Leucaena, independientemente de si ha sido presecado o no el King grass, a pesar de que el presecado y la presencia de leguminosas son razones válidas para que el pH alcance valores encima de lo normal; es por esos que dos muestras de ensilaje pueden tener el mismo $\mathrm{pH}$, pero diferentes concentraciones de ácidos y viceversa.

Por otra parte, los valores de la interacción entre la forma del forraje de King grass (fresco o presecado) vs. el porcentaje de Leucaena en la mezcla denotan que no es posible aislar la influencia de ambos factores en el $\mathrm{pH}$. Esto significa que, cuando se trata de la acidez del ensilaje, es necesario considerar cada una como un material independiente donde se combinan de independientemente la forma de la gramínea (fresca o presecada) y el porcentaje de la leguminosa; mientras que en lo referente al $\mathrm{NH}_{3}$ sí es factible afirmar que se obtiene una menor degradación relativa de las proteínas cuando se preseca el King grass antes de ensilar, puesto que el valor de la interacción no es significativo.

En general, los resultados en la fermentación de diferentes mezclas están muy ligados a factores específicos de los forrajes originales. Pero estos 
is obtained when the King grass is wilted before silage, since the value of the interaction is not significant.

Overall, the results in fermentation of different mixtures are closely linked to specific factors depending on the original forages. But those values also show that the local environmental could influence the spontaneous development of various microorganisms, since adding bacterial cultures to induce fermentation showed specific and precise effects, regardless of the forage characteristics, which can be pure legumes and other types of forage (21.22).

The influence of Leucaena has been well established, since this forage has MS high tenors (about 30\%) and experiments done on their ensilability conclude that it is good for mixed silage, but does not cause significant decreases in the $\mathrm{pH}$ of the preserved mass (3).

The proteolytic potential of the silage depends on the protein content and the affinity of the proteinase in the forage; additionally, the solubilization process of the proteins depends on a decrease in the $\mathrm{pH}$ and the content of MS in the material as an indicator of the osmotic pressure in the environment, although the proteolysis is inhibited more by the rapid drop in $\mathrm{pH}$ that by osmolarity due to limitations it imposes on the proteolytic bacteria and Clostridia (23). In addition, other factors of the composition of the original feed, such as the presence of polyphenols, also affect the preservation of legume proteins (24).

This interdependence is valid for all kinds of ensiled materials. In research with silages made from orange peels it was considered very good at $8.3 \% \mathrm{NH}_{3}$, which shows a low process of deamination and protein degradation, even when the $\mathrm{pH}$ dropped to 3.7 and produced acidity that ensured the stability of the preserved mass (25).

Furthermore, deterioration of the protein did not go above 11 and $15 \%$ of the total $\mathrm{N}$ (Table $2)$, which are accepted as limitations since at proportions higher than $\mathrm{NH}_{3}$ it is released very rapidly in the rumen of animals and causes significant urinary losses of this fraction (26). It is important to highlight that when fermentation is done by adding organic acids, and not naturally as in this investigation, lower percentages of $\mathrm{NH}_{3}-\mathrm{N}$ are obtained $(26,27)$.

$\mathrm{N}$ ammonia ratios found are in accordance with these principles, although this increases when a greater proportion of Leucaena is in the mixture. Regardless of this, the increased PB achieved valores comprueban también las influencias que podrían tener las condiciones ambientales locales para el desarrollo espontáneo de diferentes microorganismos, ya que la adición de cultivos de bacterias para conducir la fermentación ha mostrado efectos determinantes y precisos, independientemente de las características de los forrajes que pueden ser leguminosas puras y otros tipos de forrajes $(21,22)$.

La influencia de la Leucaena ha quedado bien demostrada pues este forraje se caracteriza por poseer tenores de MS elevados (alrededor de 30\%) y los experimentos hechos sobre su ensilabilidad concluyen que es buena para ensilar misturada, pero no provoca descensos notables en el $\mathrm{pH}$ de la masa conservada (3).

El potencial proteolítico de los ensilados depende del contenido de proteínas y de la afinidad de las proteinasas endógenas de los forrajes; además que el proceso de solubilización de las proteínas está en dependencia del descenso del $\mathrm{pH}$ y del contenido de MS del material, como indicador de la presión osmótica del medio, aunque la proteólisis se inhibe más fuertemente por la rápida caída del $\mathrm{pH}$ que por la osmolaridad, debido a las limitaciones que impone este al crecimiento de bacterias proteolíticas y a los Clostridios (23). Además, otros factores de la composición de los forrajes originales, como la presencia de polifenoles, también influyen en la preservación de las proteínas de las leguminosas (24).

Esta interdependencia es válida para todo tipo de material ensilado, en una investigación con ensilaje hollejos de naranja fue considerado muy bueno el $8.3 \%$ de $\mathrm{NH}_{3}$, muestra de un bajo proceso de deaminación y de degradación de las proteínas, aun cuando el pH descendió hasta 3.7 y produjo una acidez que garantizó la estabilidad de la masa conservada (25).

Además, no se alcanzó deterioro de la proteína por encima de 11 y $15 \%$ del $\mathrm{N}$ total (Tabla 2), aceptados como limitantes puesto que con proporciones superiores de $\mathrm{NH}_{3}$, este es liberado muy rápidamente en el rumen de los animales y provoca significativas pérdidas urinarias de esta fracción (26). Es importante destacar que cuando la fermentación se conduce con la adición de ácidos orgánicos, y no de forma natural como en la presente investigación, se obtienen porcentajes más bajos de $\mathrm{NH}_{3}-\mathrm{N}(26,27)$.

Las proporciones de $\mathrm{N}$ amoniacal encontradas están acorde con estos principios, a pesar de que este aumenta por una mayor proporción de Leucaena en la mezcla. Independientemente de esto el aumento de la PB que se logra es una de las principales motivaciones para ensilar gramíneas 
is one of the main motivations for using mixed silage of grasses with legumes or species of other families that are richer in this nutrient $(9,10,13,20)$.

The results that were quantified in the MS, PB and FB show the expected benefit of mixing, especially with respect to $\mathrm{PB}$, and confirm that if the chemical composition of forages is known, it could certify a MS content in silage that also ensures good preservation and high nutritional value. Under this principle, a very wet forage mixed with another drier one will improve the parameters of conservation and nutritional quality, whenever the used proportions are controlled. Hence the recommendation to combine cereal high in MS with wet forage to solve the disadvantages of both extreme situations (16).

In a similar investigation with a legume and cereal (berseem+triticale), it was found that the chemical composition in the mix is better than with just cereal, but not when compared with the legume, while fermentation favors the mixture in silage in relation to the legume alone (28), so it was preferred over the two pure silages.

From the results in fermentation measurements, bromatology, $\mathrm{pH}$ and $\mathrm{N}$ ammonia, it can be concluded that the mixed silage of fresh King grass with Leucaena is well preserved when up to $25 \%$ of the latter is included, while the previously dehydrated King grass $\left(K_{p} L\right)$ has best results when $45 \%$ legume was added. With this option the nutritional quality of silage is improved, there are benefits in conserving the ensiled mass, chemical composition and the protein content, whose solubility is not affected. Increasing proportions of Leucaena above the previous limits leads to undesirable fermentation that do not guarantee the preservation of the silage mass. con leguminosas o especies de otras familias más contenedoras de este nutriente $(9,10,13,20)$.

Los resultados que se cuantificaron en la MS, FB y $\mathrm{PB}$ permiten demostrar el beneficio previsto con la operación de mezclado, principalmente respecto a la $\mathrm{PB}$, y afirmar que si se conoce la composición química de los forrajes; se pudiera garantizar un contenido de MS en el ensilaje que asegure también una buena conservación y elevado valor nutricional. Bajo este principio si se dispone de forrajes muy húmedos su mezcla con otro más seco permitirá mejorar los parámetros de la conservación y de calidad nutritiva, siempre que se controle las proporciones empleadas. De aquí la recomendación de combinar también pajas de cereales de alto contenido de MS con forrajes húmedos para resolver las desventajas de ambas situaciones extremas (16).

En una investigación similar con una leguminosa y un cereal (berseem+titricale) se obtuvo que la composición química es mejor en la mezcla que en el cereal solo, pero no así en comparación con la leguminosa, mientras que la fermentación favorece a la mistura ensilada en relación a la leguminosa sola (28), por lo que fue preferida sobre los dos ensilajes puros.

A partir de los resultados en las mediciones de la fermentación, bromatología, pH y $\mathrm{N}$ amoniacal, es factible concluir que los ensilajes mixtos de King grass fresco con Leucaena se conservaron bien cuando se incluye hasta $25 \%$ de esta última, mientras que con el King grass deshidratado previamente $(\mathrm{KpL})$ se observaron los mejores resultados con la adición de la leguminosa hasta $45 \%$. Con esta opción se mejora la calidad nutricional de los ensilajes, por los beneficios en la conservación de la masa ensilada, en la composición química y principalmente en el tenor de proteína, cuya solubilidad no se afecta. El aumento de las proporciones de Leucaena por encima de los límites anteriores conduce a fermentaciones indeseables que no garantizan la preservación de la masa ensilada.

\section{REFERENCES}

1. Cárdenas JV, Sandoval CA, Solorio FJ. Composición química de ensilajes mixtos de gramíneas y especies arbóreas de Yucatán, México. Téc Pecu Méx 2003; 41(3): 283-294.
2. Tjandraatmadja M, MacRae IC, Norton BW. Effect of the inclusion of tropical legumes, Gliricidia sepium and Leucaena leucocephala, on the nutritive value of silages prepared from tropical grasses. J Agric Sci Cambr 1993; 120(3):397-406. 
3. Santana AA. Mejoramiento del valor nutritivo de los ensilajes tropicales mediante mezclas de gramíneas y leguminosas. [Tesis doctorado] Facultad de Medicina Veterinaria; Universidad de Granma. Granma, Cuba 2000.

4. Dewhurst RJ, Fisher WJ, Tweed JKS, Wilkins $\mathrm{RJ}$. Comparison of grass and legume silages for milk production. 1. Production responses with different levels of concentrates. J. Dairy Sci 2003; 86(8):2612-2621.

5. Merry RJ, Lee MRF, Davies DR, Dewhurst RJ, Moorby JM, Scollan ND, Theodorou MK. Effects of high-sugar ryegrass silage and mixtures with red clover silage on ruminant digestion. 1. In vitro and in vivo studies of nitrogen utilization. J Anim Sci 2006; 84(11):3049-3060. URL Disponible en: http://www.journalofanimalscience.org/ content/84/11/3049

6. Santana AA, Pérez A, Figueredo ME. Efectos del estado de madurez en el valor nutritivo y momento óptimo de corte del forraje napier (Pennisetum purpureum Schum.) en época lluviosa. Rev Mex Téc Pecu 2010; 1(3):277-286.

7. Herrera RS, González SB, Hardy C, Pedroso D. Análisis químico del pasto. Metodologías para las tablas de su composición. La Habana. Cuba: Edit. ENPES; 1980.

8. StatSoft, Inc. STATISTICA. Software de análisis de datos. Version 8.0. Tulsa, Oklahoma. USA. 2007.

9. Ojeda F, Montejo IL, López O. Estudio de la calidad fermentativa de la morera y la hierba de guinea ensilada en diferentes proporciones. Pastos y Forrajes 2006. 29(2):195-202.

10. Alpízar A, Camacho MI, Sáenz C, Campos ME, Arece J. Esperance M. Efecto de la inclusión de diferentes niveles de morera (Morus alba) en la calidad nutricional de ensilajes de sorgo (Sorghum almum). Pastos y Forrajes 2014. 37(1): 47-52.

11. Tessema Z, Baar RMT. Chemical composition, dry matter production and yield dynamics of tropical grasses mixed with perennial forage legumes. Tropical Grasslands 2006; 40:150-156.

12. Baba M, Halim RA, Alimon AR, Idris AB, Juraimi AS. Grass-legume mixtures: An analysis of dry matter yield, chemical composition, and in vitro apparent dry matter digestibility. J Food Agr Envirom 2013; 11(3-4): 995-1001.
13. Kechero Y. Effects of seed proportions of Rhodes grass (Chloris gayana) and white sweet clover (Melilotus alba) at sowing on agronomic characteristics and nutritional quality. Livestock Res for Rural Dev 2008; 20(2)20-28. URL Disponible en http//www. Irrd.org/Irrd20/2/yise20028.htm

14. Sanderson MA. Nutritive value and herbage accumulation rates of pastures sown to grass, legume and chicory mixtures. Agron J 2010; 102(2): 728-733.

15. Pihiri MS, Ngongoni NT, Maasdorp BV, Titterton M, Mupangwa JF, Sebata A. Ensiling characteristics and feeding value of silage made from browse tree legume-maize mixtures. Trop Subtrop Agroecosyst 2007; 7(3):149-156.

16. Moran J. Making quality silage. Tropical dairy farming: feeding management for smallholder dairy farmers in the humid tropics. Landlinks Press. 2005; 83-95.

17. Lambertucci DM, Pinho MRO, Gomes FA, Fernandes EC, Mistura C, Martins COM, Silva AS. Produção de silagem de capim elefante cV. Napier utilizando farinha de mandioca. Rev Sodebras 2013; 8: 74-77.

18. Eriksson T, Norell L. Nilsdotter-Linde N. Nitrogen metabolism and milk production in dairy cows fed semi-restricted amounts of ryegrass-legume silage with birdsfoot trefoil (Lotus corniculatus L.) or white clover (Trifolium repens L.). Grass Forage Sci 2012; 67(4): 546-548.

19. Keles G, Demirci U. The effect of homofermentative and heterofermentative lactic acid bacteria on conservation characteristics of baled triticale-Hungarian vetch silage and lamb performance. Anim Feed Sci Technol 2011; 164(1-2): 21-28.

20. Muhammad LR, Baba M, Mustapha A, Ahmad MY, Abdurrahman LS. Use of legumes in the improvement of silage quality of Columbus grass (Sorghum almum Parodi). Res J Anim Sci 2008; 2(4):109-112.

21. Herrera JM, Isaac ML, Rodríguez R, Zamora JF, Ruíz MA, García PM. Conservación del forraje de Lupinus rotundiflorus M. E. Jones y Lupinus exaltatus Zucc. mediante ensilaje. Revista INTERCIENCIA 2010; 35(8):592-599. 
22. Jatkauskas J, Vrotniakienè $V$, Urbšienè D. Effects of a bacterial mix inoculant on grasslegume silage fermentation and nutrition value for the dairy cows. Animal Husbandry 2008; 52: 51-59.

23. Tao L, Yu Z, Guo XS, Zhou H. Ensiling and in vitro digestibility characteristics of Ceratoides arborescens treated with lactic acid bacteria inoculants and cellulase. Afr J Biotechnol $2011 ; 10(66)$ : 14947-14953.

24. Bickel A, Friedel K, Gabel M. Factors potentially affecting proteolysis under in vitro conditions using Rostocker fermentationstest: first results. Proc Soc Nutr Physiol 2006; 15: 56-67.

25. Montejo IL, Lamela $L$, Sánchez $T$, López $\mathrm{O}$. Nota técnica: Producción de leche con ensilaje de hollejo de cítrico. Pastos y Forrajes 2008; 31(2): 179-186.
26. Jaakkola S, Kaunisto V, Huhtanen P. Volatile fatty acid proportions and microbial protein synthesis in the rumen of cattle receiving grass silage ensiled with different rates of formic acid. Grass and Forrage Sci 2006; 61:282-292.

27. Vanhatalo A, Gäddäs T. Microbial protein synthesis, digestion and lactation responses of cows to grass or grass-red clover silage diet supplemented with barley or oats. Agric and Food Sci 2006; 15:252-267.

28. El-Emam GI, Hafez YH, Behery HR, Khalifa EI, Shehata EI, Ahmed ME. Growth performance, some rumen and blood parameters of growing rahmani lambs fed rations containing triticale or berseem silages and their mixture. Egyptian J Sheep \& Goat Sci 2014; 9(1):67-76. 